\author{
KONCEPTUALIZACJA ŚMIECHU \\ W JEZZYKOWYM OBRAZIE ŚWIATA NADIEŻDY TEFFI \\ (NA MATERIALE PROZY WSPOMNIENIOWEJ)
}

\title{
WPROWADZENIE TEORETYCZNE
}

Pojęcie językowy obraz świata doczekało się wieloaspektowych i pogłębionych badań na gruncie nauki polskiej. Od lat 80. XX wieku badania w tym zakresie są prowadzone na Uniwersytecie Marii Curie-Skłodowskiej w Lublinie. Zespół językoznawców pod kierunkiem Jerzego Bartmińskiego stworzył podstawy lubelskiej szkoły etnolingwistycznej, która wniosła znaczący wkład do wiedzy o powiązaniach między językiem a kulturą. Wśród autorów publikacji opisujących zjawisko językowego obrazu świata, poza wspomnianym Jerzym Bartmińskim, warto przypomnieć Janusza Anusiewicza, Annę Dąbrowską, Renatę Grzegorczykową i Ryszarda Tokarskiego. Wiele prac poświęconych temu zagadnieniu zostało opublikowanych w roczniku Etnolingwistyka oraz serii $\mathrm{z}$ zakresu lingwistyki antropologicznej „Język a Kultura” (Językowy obraz świata; Grzegorczykowa, Pojęcie; Tokarski, Słownictwo; Bartmiński, Językowe podstawy; Tokarski, Od językowego; Anusiewicz, Problematyka; Grzegorczykowa, Punkty dyskusyjne; Żuk, Językowy).

Dorobek lubelskiej szkoły etnolingwistycznej oraz badaczy z innych ośrodków akademickich upowszechnił w polskim językoznawstwie pojęcie językowy obraz świata (JOS). Jedną z pierwszych definicji JOS na gruncie języka polskiego zawierała praca Jerzego Bartmińskiego i Ryszarda Tokarskiego:

Prof. dr. hab. IwONA ANNA NdiAYE - Uniwersytet Warmińsko-Mazurski w Olsztynie, Instytut Literaturoznawstwa, Katedra Literatur Wschodniosłowiańskich; e-mail: anna.ndiaye@uwm.edu.pl; ORCID: https://orcid.org/0000-0003-3881-0474. 
Jest to pewien zespół sądów mniej lub bardziej utrwalonych w języku, zawartych w znaczeniach słów lub przez te znaczenia implikowanych, który orzeka o cechach i sposobach istnienia obiektów świata pozajęzykowego. W tym sensie JOS jest utrwaleniem zespołu relacji zawartych w językowym ukształtowaniu tekstu, a wynikającym z wiedzy o świecie pozajęzykowym. (Bartmiński i Tokarski 72)

Założenia etnolingwistyki, opartej na pojęciu językowego obrazu świata i metodach rekonstrukcji konceptów kulturowych, zostały sformułowane w I tomie rocznika Etnolingwistyka:

Centralnym pojęciem wyznaczającym jej główny przedmiot zainteresowań będzie pojęcie językowego obrazu świata, rozumianego jako obraz „naiwny”, leżący u podstaw języka, utrwalony w strukturze gramatycznej i znaczeniach słów, także w strukturze i znaczeniach tekstów. (Bartmiński, Słowo 5)

Na potrzeby naszych rozważań za Januszem Anusiewiczem przyjęliśmy, że językowy obraz świata (JOS) to określony sposób ujmowania przez język rzeczywistości:

JOS to określony sposób ujmowania przez język rzeczywistości (zarówno pozajęzykowej, jak i językowej), istniejący w semantycznych, gramatycznych, syntaktycznych i pragmatycznych kategoriach danego języka naturalnego [...] to określony sposób odwzorowania świata dany w pojęciowym rozczłonkowaniu zawartym w języku ujmującym ten świat. (Anusiewicz, Lingwistyka 113)

\section{BADANIE KONCEPTÓW \\ W KATEGORIACH FENOMENU JĘZYKOWEGO}

Rekonstrukcja językowego obrazu świata może odbywać się na podstawie semantycznych obrazów poszczególnych słów oraz „modeli konceptualnych ukrytych za ciągami jednostek językowych" (Tokarski, Przeszłość 13). Dlatego też badanie konceptów w kategoriach fenomenu językowego pozostaje w centrum uwagi zarówno językoznawców, jak i literaturoznawców. Koncept, jako jedno z kluczowych pojęć współczesnej lingwistyki, funkcjonuje w różnorodnych wariantach terminologicznych. Na potrzeby podjętej przez nas analizy konceptualnej za punkt wyjścia przyjęliśmy założenie rosyjskiego językoznawcy i semiotyka Jurija Stepanowa, którego zdaniem koncepty kulturowe (w odróżnieniu od znaczeń leksykalnych wyrazów) zawierają różnorodną informację: znaczenie pojęciowe funkcjonujące $\mathrm{w}$ języku 
ogólnym, specyficzne elementy semantyczne, asocjacje semantyczne, interpretacje wartościujące i in. (Stepanov) ${ }^{1}$.

Koncept możemy zatem rozpatrywać jako element indywidualnego obrazu świata opartego na analizie tekstu literackiego oraz specyfice organizacji warstwy leksykalnej. W tym znaczeniu używamy pojęcia konceptu literackiego, który rozumiemy jako pojęcie myślowe ukształtowane w świadomości pisarza w rezultacie jego doświadczenia, wyobrażeń na temat rzeczywistości, przeżyć, uczuć, obrazów artystycznych, wyrażone za pomocą różnorodnych środków językowych (Churilina). Z uwagi na fakt, że werbalizacja konceptu w tekście literackim jest uwarunkowana autorskim postrzeganiem świata, w badaniach literaturoznawczych utrwaliło się założenie, że analiza konceptualna pozwala rozszerzyć ramki tradycyjnego spojrzenia na problem ludzkiej egzystencji o perspektywę zaproponowaną przez twórcę. Jak zasadnie zauważa Irina Popadeykina, analizująca koncept CMEPTb (ŚMIERĆ) w utworach prozatorskich współczesnych pisarzy, specyfika werbalizacji konceptu w tekście literackim uwarunkowana jest autorskim postrzeganiem świata (Popadeykina). Do konceptów artystycznych, które wyrażają szerokie emocjonalne spektrum uczuć, poza wspomnianym motywem mortalnym, należą również koncepty жизнь, ЛюБОВь, ДОМ, СМЕХ (ŻYCIE, MIŁOŚĆ, DOM, ŚMIECH) $i$ in.

Spośród wymienionych konceptów artystycznych postanowiliśmy wyróżnić koncept CMEX jako ten, który zajmuje ważne miejsce w autorskim obrazie świata Nadieżdy Teffi (właśc. Buczyńska, z d. Łochwicka, 1872-1952) pisarki pierwszej fali emigracji rosyjskiej. Teffi należała do najbardziej rozpoznawalnych i najciekawszych postaci w literaturze rosyjskiej pierwszej połowy XX wieku. W przedrewolucyjnej Rosji została okrzyknięta „królową humoru". Również na obczyźnie, w ekstremalnych warunkach, w jakich przyszło żyć rosyjskim emigrantom, Teffi szybko zdobyła popularność podobną do tej w kraju. Zasłynęła przede wszystkich jako autorka utworów satyrycznych oraz felietonów. Twórczość ta zyskała wysoką ocenę krytyków i pisarzy, reprezentujących niekiedy bardzo odległe pozycje ideowe oraz twórcze. Wśród pisarzy emigracyjnych, którzy bardzo pochlebnie wypowiadali się na temat artyzmu jej prozy, byli m.in. Mark Ałdanow, Aleksandr Kuprin, Aleksandr Amfiteatrow, a nawet krytyczny z reguły Iwan Bunin ${ }^{2}$.

\footnotetext{
${ }^{1}$ Por. określenie wprowadzone przez Władimira Karasika: „концепт - многомерное смысловое образование, в котором выделяются ценностная, образная и понятийная стороны” (Karasik 129).

${ }^{2}$ Więcej na ten temat piszę we wstępie do monografii, którą poświęciłam tożsamości poetyckiej Nadieżdy Teffi (Pod maska Talii 7-27).
} 


\section{METODOLOGIA, CEL I ZAKRES BADAŃ}

Niniejszy artykuł stanowi próbę rekonstrukcji i analizy niewielkiego fragmentu językowego obrazu świata - konceptu CMEX, zawierającego wyobrażenia i informację o jednej z głównych emocji - radości.

Celem artykułu jest przedstawienie semantycznego konceptu CMEX oraz sposobów jego językowej reprezentacji w prozie wspomnieniowej Teffi. Materiał leksykalny do analizy wyodrębniliśmy na podstawie wspomnień, które częściowo ukazały się za życia autorki, częściowo pośmiertnie. Wspomnienia (Воспоминания) po raz pierwszy zostały opublikowane na łamach gazety Возрождение (grudzień 1928 r. - styczeń 1930 r.). Naszą uwage koncentrujemy również na tekstach, które w różnym czasie były publikowane w emigracyjnych wydawnictwach periodycznych, a następnie zebrane w tomie Moja kronika (Моя летопись, wyd. Вагриус) ${ }^{3}$. O wyborze powyższych utworów do analizy zdecydowały zarówno względy historyczne, jak też ich walory artystyczne oraz fakt, że - w przeciwieństwie do innych utworów prozatorskich Teffi - nie stały się one przedmiotem wszechstronnej i dogłębnej analizy literaturoznawczej i językoznawczej ${ }^{4}$.

Biorąc pod uwagę fakt, że $\mathrm{w}$ analizie konceptu literackiego rolę podstawowych środków językowych odgrywają leksemy, dokonaliśmy wyboru kluczowych leksemów w prozie wspomnieniowej Teffi. Wybór ten został przeprowadzony na podstawie analizy ilościowo-jakościowej oraz kryterium pojemności semantycznej, tj. zdolności słowa do tworzenia związków skojarzeniowych z możliwie największą liczbą innych słów ${ }^{5}$. Przeprowadzona przez nas analiza była ukierunkowana na zbadanie leksykalnego nasycenia wybranego konceptu w indywidualno-autorskim stylu pisarki. Do szczegółowej analizy środków językowych i artystycznych wykorzystaliśmy

\footnotetext{
${ }^{3}$ Rękopis książki autorka osobiście wysłała do nowojorskiego Wydawnictwa im. Czechowa, nie doczekała się jednak publikacji. Trzy lata po śmierci emigrantki rękopis został zwrócony jej córce, Walerii Grabowskiej. W 1955 r. fragmenty książki opublikowano w czasopiśmie Boзрождение. Jako pierwsze ukazały się wówczas wspomnienia o Aleksandrze Kuprinie i Wsiewołodzie Meyerholdzie. Rękopis, znajdujący się w zbiorach Rosyjskiego Państwowego Archiwum Literatury i Sztuki (РГАЛИ), składa się z materiałów prasowych, wariantów maszynopisów, przepisywanych na różnych maszynach do pisania i w różnym czasie. Pośmiertne wydanie z 2015 r. stanowi autorską koncepcję jej redaktora St. Nikonienki (Teffi). Za tę porządkującą uwagę wyrażam wdzięczność prof. Dmitrijowi Nikołajewowi z Instytutu Literatury Światowej im. A. M. Gorkiego Rosyjskiej Akademii Nauk w Moskwie.

${ }^{4} \mathrm{Na}$ temat gatunkowej specyfiki wspomnień Teffi, ze szczególnym uwzględnieniem kategorii czasu i przestrzeni zob. Nechvolod 72-79.

${ }^{5}$ Por. kryterium opisane w pracy Jurija Karaułowa (160).
} 
oryginalną bazę słownictwa opracowaną przez nas na podstawie wydania Moja kronika (Моя летопись), obejmującego Wspomnienia (19-216) oraz 23 szkice wspomnieniowe (221-454). Analiza częstotliwości użycia jednostek leksykalnych i wyodrębnione na jej podstawie listy rankingowe pozwoliły wskazać ciąg powiązanych ze sobą pojęć. W procesie analizy odwołaliśmy się do metodologii zaproponowanej przez Josifa Sternina, który rozpatruje strukturę konceptu z perspektywy pola, które posiada jądro i peryferie (Sternin 61-63). Zastosowanie takiego podejścia pozwoliło wyróżnić w strukturze konceptów różnorodne jednostki mentalne autorskiego obrazu świata, werbalizowane w tekstach literackich (sensy i wyobrażenia obiektywne oraz indywidualno-autorskie) ${ }^{6}$.

Ponadto w badaniu wykorzystano metodę opisową oraz analizę funkcjonalno-stylistyczną.

\section{ANALIZA ILOŚCIOWO-JAKOŚCIOWA}

W celu wyeksplorowania materiału badawczego zastosowaliśmy metodę ilościowo-jakościową, opartą na statystyce jednostek. Na podstawie stworzonej bazy ustaliliśmy, że do kluczowych słów reprezentujących CMEX w prozie wspomnieniowej Teffi należą następujące leksemy: веселость, веселье, забава, несмешка, подхихикиванье, смех, ульбка, усмешка, усмешечка, хохот, иутка, юмор; весело, забавно, смешно; весельй, забавный, смешной; веселить, веселиться, высмеять, забавлять, забавляться, засмеяться, повеселиться, подиутить, посмечваться, просмеяться, рассмешить, рассмеяться, смешить, смеяться, ульббаться, ульгбнться, усмехаться, усмехнуться, иутить, хихикать, хихикнуть, xoxomamb.

Opracowanie tabelaryczne polegało na przygotowaniu wykazu słownictwa z uwzględnieniem takich parametrów, jak: frekwencja, forma użycia, wielkości procentowe użyć w stosunku do pozostałych elementów leksykalnych. Listy rankingowe zostały opracowane dla podstawowych części mowy: rzeczowników, czasowników/imiesłowów, przymiotników i przysłówków. Na podstawie zbiorczych danych liczbowych uwzględnionych w listach frekwencyjnych utworzyliśmy listy rankingowe. Wykazy poszczególnych części mowy (w porządku malejącym) uwzględniają częs-

\footnotetext{
${ }^{6}$ Metodę, zaproponowaną przez Josifa Sternina, wykorzystała w swoich badaniach m.in. Jelena Dziuba, analizująca śmierć jako fenomen językowy w poezji Mariny Cwietajewej (Dzyuba 181-189).
} 
tość ich użycia oraz wielkość procentową w stosunku do użycia wszystkich wyrazów, która dla analizowanych tekstów wyniosła 96.574. Wyniki analizy ilościowej przedstawiają tabele zamieszczone poniżej:

Tabela 1. Lista rankingowa rzeczowników

\begin{tabular}{|c|l|c|c|}
\hline RANGA & RZEсZоWNIK & FREKWENCJA & $\%$ \\
\hline I & смех & 21 & 0,022 \\
\hline II & ульбка & 8 & 0,008 \\
\hline III & усмешка & 8 & 0,008 \\
\hline IV & иутка & 7 & 0,007 \\
\hline V & забава & 2 & 0,002 \\
\hline VI & насмешка & 1 & 0,001 \\
\hline VII & веселье & 1 & 0,001 \\
\hline VIII & веселость & 1 & 0,001 \\
\hline IX & подхихикиванье & 1 & 0,001 \\
\hline X & хохот & 1 & 0,001 \\
\hline XI & юмор & 1 & 0,001 \\
\hline
\end{tabular}

Tabela 2. Lista rankingowa czasowników/imiesłowów

\begin{tabular}{|c|c|c|c|}
\hline RANGA & CZASOWNIкі/IмIESŁOWY & FREKWENCJA & $\%$ \\
\hline I & смеяться & 24 & 0,025 \\
\hline II & ульбаться & 13 & 0,013 \\
\hline III & засмеяться & 12 & 0,012 \\
\hline IV & иутить & 6 & 0,006 \\
\hline V & хохотать & 6 & 0,006 \\
\hline VI & ульбнуться & 5 & 0,005 \\
\hline VII & усмехнуться & 5 & 0,005 \\
\hline VIII & веселить & 3 & 0,003 \\
\hline IX & усмехаться & 3 & 0,003 \\
\hline
\end{tabular}




\begin{tabular}{|l|l|l|r|}
\hline X & вьсмеять & 2 & 0,002 \\
\hline XI & рассмеяться & 2 & 0,002 \\
\hline XII & хихикать & 2 & 0,002 \\
\hline XIII & веселиться & 1 & 0,001 \\
\hline XIV & забавлять & 1 & 0,001 \\
\hline XV & забавляться & 1 & 0,001 \\
\hline XVI & повеселиться & 1 & 0,001 \\
\hline XVII & подчутить & 1 & 0,001 \\
\hline XVIII & посмеиваться & 1 & 0,001 \\
\hline XIX & просмеяться & 1 & 0,001 \\
\hline XX & рассмешить & 1 & 0,001 \\
\hline XXI & смешить & 1 & 0,001 \\
\hline XXII & хихикнуть & 1 & 0,001 \\
\hline
\end{tabular}

Tabela 3. Lista rankingowa przymiotników

\begin{tabular}{|c|c|c|c|}
\hline RANGA & PRZYмIотNIKI & FREKWENCJA & $\%$ \\
\hline I & забавный & 15 & 0,015 \\
\hline II & весельй & 14 & 0,014 \\
\hline III & смешной & 8 & 0,008 \\
\hline
\end{tabular}

Tabela 4. Lista rankingowa przysłówków

\begin{tabular}{|c|c|c|c|}
\hline RANGA & PRZYMIOTNIKI & FREKWENCJA & $\%$ \\
\hline I & смешно & 13 & 0,013 \\
\hline II & забавно & 3 & 0,003 \\
\hline III & весело & 2 & 0,002 \\
\hline
\end{tabular}

$\mathrm{Na}$ podstawie liczby porządkowej na liście rankingowej możemy stwierdzić, że w prozie wspomnieniowej Teffi słowami o najwyższej randze pozostają: смех, ульбка, усмешка; смеяться, ульббаться, засмеяться; забавный, весельй; смешно. Analiza list frekwencyjnych poszczególnych części 
mowy pozwala określić ich rolę w tekście literackim. Wnioski dotyczące użycia poszczególnych jednostek leksykalnych do budowy tekstu pozwala prześledzić poniższe zestawienie:

\begin{tabular}{|l|c|c|c|}
\hline \multicolumn{1}{|c|}{$\begin{array}{c}\text { RodZAJ JEDNOSTKI } \\
\text { LEKSYKALNEJ }\end{array}$} & LiczBA JEDNOSTEK & LicZBA UŻYĆ & $\%$ \\
\hline Rzeczownik & 11 & 52 & 0,054 \\
\hline Czasownik i imiesłów & 22 & 93 & 0,096 \\
\hline Przymiotnik & 3 & 37 & 0,038 \\
\hline Przysłówek & 3 & 18 & 0,019 \\
\hline \multicolumn{1}{|c|}{ OGÓŁEM: } & 39 & 200 & $\approx 0,207$ \\
\hline
\end{tabular}

$\mathrm{Na}$ podstawie powyższego zestawienia możemy stwierdzić, że w słowniku literackim Teffi największą rolę odgrywają czasowniki i rzeczowniki. Głównymi leksemami reprezentującymi koncept CMEX są rzeczownik cмex i czasownik смеяться.

\section{ANALIZA KONCEPTUALNA}

Za najbardziej uniwersalny z punktu widzenia naszych rozważań uznaliśmy opis struktury konceptu opracowany przez rosyjskiego językoznawcę Josifa Sternina, na którego podstawie wyróżniliśmy wyobrażenia obiektywne oraz indywidualno-autorskie (Sternin 61-63). Pod pojęciem obiektywnych należy rozumieć takie znaczenia dowolnego pojęcia, które podają źródła leksykograficzne oraz reprezentują wiedzę potoczną, tj. odzwierciedlające tę sferę wyobrażeń o świecie, która jest wspólna dla wszystkich ludzi. Z drugiej strony należy uwzględnić indywidualne, autorskie rozumienie istoty przedmiotów i zjawisk, tj. takie, które nie są zapisane w słownikach, natomiast pojawiają się w utworach literackich:

Znaczenia konotacyjne (...) określane indywidualnymi, niezależnie od tego, czy są obecne w konceptosferze innych użytkowników języka w rezultacie wspólnego doświadczenia społecznego, historycznego i kulturowego. Znaczenia indywidualno-autorskie reprezentują peryferie i zawierają przestrzenno-czasowe, percepcyjne i aksjologiczne charakterystyki konceptu (...) (Popadeykina 88-89) 
Tym samym językowy obraz konceptu to złożona struktura kognitywna, która składa się z rdzenia pojęciowego, odpowiadającego znaczeniu leksykalnemu oraz warstw peryferyjnych, semantycznie rozszerzających i dopełniających strukturę konceptu. Analizę konceptualną prozy wspomnieniowej Teffi rozpoczniemy zatem od wyznaczenia jądra konceptu, co pozwoli na dalszym etapie wyróżnić jego komponenty peryferyjne oraz indywidualne. Głównym leksemem reprezentującym koncept CMEX w języku rosyjskim jest rzeczownik cмex ${ }^{7}$, który w leksykografii rosyjskiej definiowany jest jako:

Характерные, прерывистые звуки, создаваемые короткими выдыхательными движениями, как проявление веселья, радости, удовольствия и т.п. (Slovar' russkogo yazyka 521)

Прерывистые, характерные звуки, вызываемые короткими и сильными выдыхательными движениями как проявление радости, веселья, удовольствия и т.п. (иногда при нервных потрясениях); безл. сказ. разг. О чем-л. производящем комическое впечатление, способном рассмешить; смешно. (Slovar' sovremennogo russkogo, 1367)

$\mathrm{Na}$ podstawie powyższych definicji słownikowych możemy zauważyć, że zasadniczy komponent jądra konceptu CMEX stanowią pozytywne emocje w życiu człowieka: radość, szczęście, miłość, zadowolenie itd. Wokół leksemu смеx, będącego jednocześnie nazwą konceptu, koncentrują się pozostałe jednostki reprezentujące i utrwalające koncept CMEX w języku, nр. веселье, радость, удовольствие itp.

Przejdźmy zatem do kontekstów aktualizujących pozytywne uczucia i emocje w prozie wspomnieniowej Teffi. Dokonana przez nas analiza środków językowych pozwala stwierdzić, że również w tym przypadku śmiech wyraża przede wszystkim radość, np. „Мы едем! Их тихий и радостный смех”; „Обрывки песен, веселый говор и смех доносились из салона”. Pozytywne uczucia $\mathrm{w}$ powyższych kontekstach są aktualizowane poprzez słowa i związki wyrazowe $\mathrm{z}$ zawartym $\mathrm{w}$ nich potencjałem semantycznym: благо, могучая сила, дружелюбно, дружеский, значительнее, глубже, нежный, радость, радостный, свободный, счастье, яркий, яростный itd.

Natomiast indywidualno-autorskie znaczenia reprezentujące peryferie analizowanego przez nas konceptu mają różną konotację. Uczucia i emocje wyrażane za pomocą śmiechu w świecie przedstawionym prozy Teffi mogą

\footnotetext{
${ }^{7} \mathrm{Na}$ temat semantycznego i kognitywnego opisu konceptów улыБка і CMEX w językowym obrazie świata na gruncie języka rosyjskiego zob. Dmitrieva 50-55; Kuznetsov.
} 
być zarówno pozytywne, negatywne, jak i neutralne. Sytuacje, w których śmiech wyraża negatywne emocje, nie należą do wyjątkowych. Niekiedy oznacza szyderstwo, drwinę, kpinę, zaskoczenie, nieszczerość, smutek. Negatywne uczucia $\mathrm{w}$ powyższych kontekstach są aktualizowane poprzez słowa i związki wyrazowe $\mathrm{z}$ zawartym $\mathrm{w}$ nich potencjałem pejoratywnym pod względem semantyki: холодный, ненавидявший, яростно itd.

Dla indywidualno-autorskich znaczeń i wyobrażeń konceptu typowe są związki atrybutywne, w których wyrazem określanym jest leksem cмex. W tego typu związkach możemy zauważyć, że zaakcentowano określone cechy wzrokowe i dźwiękowe charakterystyki konceptu, np. „Их тихий и радостный смех". W analizowanych tekstach nie występują natomiast takie określenia, jak: весельй, звонкий, громкий, тихий, глухой, приглушенный, сдавленныцй itp. W pojedynczych przypadkach autorka zdecydowała się na porównanie śmiechu do dźwięków wydawanych przez zwierzę: „Доведет приятеля до белого каления и потом рот разинет и из самого нутра: - Кхра-кхра-кхра. Утиный смех. Кряква”; „Выпучит глаза, разинет рот и вдруг закрякает густым утиным басом: кхра-кхра-кхра”; „Он выпучил глаза, разинул рот и вдруг закрякал по-утиному самым добродушным нутряным смехом".

Oprócz omówionej powyżej grupy najbardziej rozpowszechnionych związków łączliwych w analizowanych tekstach występują ponadto związki podmiotowo-predykatywne. Pod względem budowy są to połączenia podmiotu logiczno-gramatycznego i orzeczenia. Ponadto liczne są związki predykatywne, które stanowią złożoną formę orzeczenia. Przykłady użycia różnego typu związków przedstawia poniższe zestawienie.

Leksem Czasownik Lokalizacja

cmex благословляться Вспоминала его стихи, где даже смех благословляется, потому что он детский.

выдавать Но его выдавал его смех.

доноситься Обрывки песен, веселый говор и смех доносились из салона.

захватывать Пышный зал хохочет, аплодирует, смех захватывает тех, кто толпится за кулисами.

ненавидеть В одном из первых рассказов был у него такой мальчик, ненавидевший жизнь и смех 


\begin{tabular}{|c|c|c|}
\hline & & $\begin{array}{l}\text { и мечтавший о звездах, где живут мудрые } \\
\text { звери и никто никогда не смеется. }\end{array}$ \\
\hline & нравиться & Мне особенно нравился его смех. \\
\hline & (не) слышать & $\begin{array}{l}\text { И есть люди, которые не слышат могучей силы } \\
\text { смеха. }\end{array}$ \\
\hline & услышать & $\begin{array}{l}\text { Услышишь суд глупца и смех толпы холод- } \\
\text { ной... }\end{array}$ \\
\hline $\begin{array}{l}\text { (om) } \\
\text { смexa }\end{array}$ & пропадать & $\begin{array}{l}\text { Чех старался, и прогнать его было жалко, но } \\
\text { мы пропадали, я от смеха, Лоло - от отчаяния. }\end{array}$ \\
\hline (во) смех & верить & $\begin{array}{l}\text { Я верю в творящего Бога }[. . .] \\
\text { Их тихий и радостный смех. }\end{array}$ \\
\hline (со) смехy & помирать & $\begin{array}{l}\text { Только какая-то баба, торговавшая бубликами, } \\
\text { помирала со смеху, глядя на меня... }\end{array}$ \\
\hline смехом & закрякать & $\begin{array}{l}\text { Он выпучил глаза, разинул рот и вдруг за- } \\
\text { крякал по-утиному самым добродушным нут- } \\
\text { ряным смехом. }\end{array}$ \\
\hline & ответить & $\begin{array}{l}\text { Ответил на японскую войну „Красным сме- } \\
\text { хом” }\end{array}$ \\
\hline & торговать & И очень скоро бросила „торговать смехом”. \\
\hline
\end{tabular}

Integralnym komponentem jądra konceptu CMEX pozostaje leksem ульббка. Werbalizacja tego pola semantycznego jest osiągana za pomocą słów i wyrażeń, w których aktualizowane jest znaczenie: „движение мышц лица (губ, глаз), показывающее расположение к смеху или выражающее радость, удовольствие, иронию и т.п.” (Slovar' russkogo yazyka, 619). W autorskim wyobrażeniu bohaterowie, uśmiechając się, wykonują określony ruch mięśni:

a) ust: „- Улыбайтесь, ради Бога, улыбайтесь, - шепчет Гуськин, растягивая рот в зверской улыбке, как «L'homme qui rit»”; „Выпучит глаза, разинет рот и вдруг закрякает густым утиным басом: кхра-кхракхра”; „У нас сегодня концерт, мы же гуляем,- убеждал он кого-то и улыбался побелевшими губами";

b) części twarzy: „Улыбнулся мелкими лучиками сухих морщин”; „Я, удивленно приподняв брови, взглянула на него и спокойно усмехнулась"; 
c) innych części ciała: „Немец улыбается, патриотическая жилка пляшет вовсю”; „Элегантные молодые люди усмехались, чуть-чуть пожимали плечами".

Zgodnie z pojęciem znaczeń obiektywnych uśmiech wyraża pozytywne emocje: radość, błogość czy też chęć przypodobania się komuś (np. „Часто появлялись незнакомые мне личности, но улыбались и угощались совсем так же, как и знакомые”; „- Мы ничего себе выехали, - блаженно улыбаясь, рассказывал какой-нибудь скромный парикмахер с Гороховой улицы”; „Он улыбнулся, польщенный”). Podstawowym środkiem werbalizacji danego semantycznego pola są następujące określenia: бесnечная, добродушная, интимная, яростная itp.

Mikrokontekst ma również potencjał neutralny. W takim przypadku użycie leksemów смеяться, улыбаться wyrażane jest bez użycia słów oceniających (np. „Я засмеялась”; „- Это действительно очень бы оживило газету, - засмеялся он”; „Он засмеялся и дал Гусеву десятирублевый золотой”; „Я засмеялась и, показывая на него, сказала Распутину”).

Śmiech może także oznaczać zmianę uczuć lub nastroju (np. „Офицер, молодой белокурый малый, повернулся к нам, посмотрел внимательно и вдруг улыбнулся удивленно, широко и радостно”; „Морская власть засмеялась и выразила сомнение...”; „-Та-ак! мрачно сказал «сам». Сдвинул брови. Прочитал. И вдруг грозный рот его медленно поехал вбок в интимной улыбке: - Это мне... захотелось для автографа!"). Najliczniej jednak jest reprezentowana gama negatywnych emocji i uczuć. Śmiejąc się lub uśmiechając się postaci:

a) boją się: „- Нах, ауф, хинтер, небен, ин, штеен, мить дем аккузатив, - улыбаясь, щебетала Оленушка”; „,- Улыбайтесь, когда разговариваете, может, кто, не дай Бог, подсматривает".

b) źle się czują psychicznie: „Элегантные молодые люди усмехались, чуть-чуть пожимали плечами, точно участвовали в нелепом анекдоте, о котором потом забавно будет порассказать";

c) martwią się, smucą się: „Пантелеймонов и смеялся, и огорчался”;

d) niepokoją się: „Гуськин смущенно усмехнулся”; „Улыбались, смущались, шутили”; „Элегантные молодые люди в щегольских костюмчиках смущенно улыбались, показывая, что понимают шутку";

e) wyrażają wątpliwości, niepewność: „Морская власть засмеялась и выразила сомнение";

f) wyrażają zdziwienie: „Я, удивленно приподняв брови, взглянула на него и спокойно усмехнулась"; 
g) wyrażją obojętność: „Услышишь суд глупца и смех толпы холодной...";

h) wyrażają pobłażliwość,: „Журналист снисходительно улыбнулся”; „- Так и не понимаете? - усмехался он”;

i) ukrywają podstęp: „Дядюшка лукаво улыбнулся”; „Ленин (он сидел рядом) покосил на меня узким лукавым взглядом и рассмеялся".

j) ukrywają emocje: „Он загадочно усмехается”; „Он загадочно усмехнулся и ушел - пухлый, сонный, масленый”; „Гуськин загадочно улыбнулся”; „Положила яйцо в корзинку с провизией и спокойно сидит, улыбается".

Aktualizatorami emocji negatywnych są:

a) epitety oceniające: деланный, зверская, лукавый, нелепый itр.;

b) czasowniki (najczęściej używane z zaprzeczeniem): „И вдруг - о, paдостное чудо! - после первых же трепетных фраз лицо одного из судей расплывается в улыбку”; „Погасла улыбка, отлетела шутка, отмечать главное устали глаза”; „Тихий, полусонный, он не спорил и не смеялся”; „Они не веселились”; „Поэтому очень бережно обходился с молодыми начинающими поэтами, слушал их порою прескверные стихи внимательно и серьезно и строгими глазами обводил присутствовавших, чтобы никто не смел улыбаться"; „Я очень люблю писателей с юмором, но специалистов-юмористов, старающихся непременно смешить, совсем не люблю”; „Господи! Какой фальшивый голос! Только бы не рассмеяться...”.

W językowym obrazie świata Teffi śmiech jest wykorzystywany nie tylko w znaczeniu dosłownym, lecz także przenośnym, nр. „И фасончик - прямо ножка смеется!" (w znaczeniu: pasuje, ładnie wygląda). Pisarka chętnie charakteryzowała śmiech poprzez użycie określeń o znaczeniu przenośnym, nadając mu cechy ludzkie, np. „Смех его был добродушный, детский и какой-то беззащитный”; „Вспоминала его стихи, где даже смех благословляется, потому что он детский”.

Słownictwo tworzące jądro i obszary peryferyjne konceptu CMEX stanowi integralną część stylistyki prozy wspomnieniowej Teffi. Do różnorodnych środków ekspresji językowej wzmacniających emocjonalność i obrazowość wypowiedzi należą związki frazeologiczne, które także odnoszą się do problemu znaczeń przenośnych. Korzystając z klasyfikacji zleksykalizowanych połączeń wyrazowych wprowadzonych przez Wiktora Winogradowa (Vinogradov 28), wyodrębniliśmy następujące grupy:

a) stałe związki frazeologiczne, nр. „не до смеху”, „на смех”, „смех берет (взял)"; 
b) związki frazeologiczne łączliwe, np. „И все надо мной смеялись: большой, толстый и наденет шапочку с ленточками";

c) związki frazeologiczne o znaczeniu przenośnym, np. „Только какаято баба, торговавшая бубликами, помирала со смеху, глядя на меня...”; „И вдруг - о, радостное чудо! - после первых же трепетных фраз лицо одного из судей расплывается в улыбку".

Teffi chętnie korzystała także z tych środków językowych, które pozwalały podkreślić emocjonalność wypowiedzi, a także zaskoczenie, zdenerwowanie (nр. ужасно любит, ужасно рад, ужасно здоровые itp.). Natomiast wyrażenie ужасно смешной wykorzystywała do opisu sytuacji, którym towarzyszyły skrajnie negatywne emocje bohaterów, a niekiedy wręcz zagrażających ich życiu:

Думаю все-таки, что любили его не за это, а за бесшабашную удаль и особое веселое молодечество. Рассказывали, как он в офицерских погонах на плечах с громким свистом проскакал по деревне, занятой большевиками.

- Почему же они в вас не стреляли?

- Очень уж обалдели. Глазам своим не верили: белый офицер и вдруг по деревне едет. Выскочили, глаза выпучили. Ужасно смешно! (Teffi 212)

W poniższym fragmencie fraza ужасно смешной została wypowiedziana przez oszukaną, zrozpaczoną bohaterkę, która znalazła się w sytuacji bez wyjścia. W takich okolicznościach można spodziewać się zdecydowanie odmiennej reakcji. Za typowe należałoby uznać krzyk, rozpacz i łzy. Skrajne jednak emocje towarzyszące bezradnej i zszokowanej bohaterce wywołują u niej jedynie nerwowy śmiech. Poniższy przykład obrazuje jeszcze jedną figurę stylistyczną, którą chętnie wykorzystywała Teffi. Osiągnięciu efektu stylistycznego polegało na celowym powtórzeniu tego samego słowa lub wyrażeń w kolejnej części konstrukcji syntaktycznej:

Я молчала, ошеломленная, и вдруг, не знаю почему, вся эта история показалась мне ужасно смешной.

- Чего же вы смешной? - ужасался В. - Они же вас надули. Передумали и даже не дали знать.

- Вот это-то и смешной.

В. схватился за голову.

- Она смеется, когда я в жалком отчаянии! А что будет с моей девочкой! Маленькая моя Лелюся, Лелюсевич мой! (Teffi 144) 
Należy zaznaczyć, że wszelkiego typu powtórzenia są jednym z najbardziej rozpowszechnionych środków stylistycznych w prozie Teffi. Do tej grupy zaliczymy gry z różnymi formami morfologicznymi, utworzonymi od tego samego rdzenia, lub wielokrotne użycie wybranych elementów słowotwórczych, które odgrywały ważną rolę w rytmizacji tekstu (np. „Вдруг наши юнги чему-то засмеялись, закричали...”; „Но публика засмеялась раз, засмеялась два и пошла веселиться”; „Гуськин смущенно усмехнулся. - Имя? Так вы же станете смеяться. - Ну Господь с вами. Почему мы будем смеяться. - Ей-Богу, будете смеяться. Я не скажу").

Dla indywidualnego stylu Teffi charakterystyczne jest również szerokie wykorzystywanie słów odnoszących się do sfery języka potocznego. Dodatkowe nacechowanie stylistyczne autorka osiągała dzięki użyciu zdrobnień. Reprezentatywne użycia leksemów усмешка і усмешечка prezentują następujące przykłady: „К дамам принято относиться с легкой усмешечкой и даже недоверием”; „В силу особенности своего таланта привык смотреть на жизнь и людей немножко иронически, отмечая все усмешкой, шуткой, острым словцом”; „О своей молодости Фондаминский говорил немного и всегда с усмешкой”; „Когда долго и мучительно умирала его жена, одна из его приятельниц с усмешкой спросил...”; „И в другой раз с усмешкой рассказал, как было одно деловое собрание, на которое его совсем не позвали. - Задаром отдам, - повторяет с усмешкой Коноплев. Шагнет понуро, с упорной и горькой усмешкой на устах".

Zbadanie struktury i funkcjonowania konceptu CMEX, a także implicytnych sposobów jego werbalizacji w języku Teffi nieuchronnie przywodzi na myśl głębszą strukturę narracyjną prozy wspomnieniowej. Zdolność do rozumienia humoru i naturalna umiejętność śmiania się to ważne kryteria opisu i oceny otaczającego świata. Prezentując poszczególne sylwetki pisarzy i krytyków, Teffi odwoływała się do tych właśnie cech. Tak było w przypadku charakterystyki osobowości Fiodora Sołoguba, Władimira Złobina, Dmitrija Mierieżkowskiego i Zinaidy Gippius. Obrazują to poniższe cytaty:

Вот эту смертельную усталость и выражало всегда его лицо. Иногда где-нибудь в гостях за столом он закрывал глаза и так, словно забыв их открыть, оставался несколько минут. Он никогда не смеялся. Такова была внешность Сологуба. (Teffi 249)

Внешность у Мережковского была особенная. Маленький, худенький, последние годы совсем искривленный, но примечательно было не это - его лицо. Оно было мертвенно-бледно, с ярко-красным ртом, и когда он говорил, были видны также красные десны. В этом было что-то жуткое. Вампир. 
Он никогда не смеялся. Вообще они оба абсолютно не понимали юмора. Мережковский даже как-то злобно не понимал. Иногда нарочно расскажешь им какую-нибудь очень смешную историю, просто чтоб посмотреть, что из этого выйдет. Полное недоумение. (Teffi 289)

Z kolei w polemice z Dmitrijem Mierieżkowskim Teffi cytowała utwór Nikołaja Gogola pt. Teatralny rozjazd (Театральный разъезд после представления новой комедии, 1836). Odwołując się do autorytetu mistrza groteski i niezrównanego satyryka-humorysty, Teffi definiowała także koncepcję własnej twórczości:

- Между прочим, зачем вы в ваших произведениях отводите место комизму? Я не люблю комизма, - сказал он мне как-то.

„Комизмом” он заменял слово „юмор”. Вероятно, из презрения.

Тогда я указала ему на отношение Гоголя к юмору.

- Вот послушайте: „Смех значительнее и глубже, чем думают. На дне его заключен вечно бьющий родник, который углубляет предмет. Насмешки боится даже тот, который уже ничего не боится на свете. И есть люди, которые не слышат могучей силы смеха. Многие говорят, что смешно - то низко, только тому дают название высокого, что произносится суровым, напряженным голосом".

Мережковский страшно обиделся. (Teffi 290-291)

Dygresyjne nawiązanie do powieści Martwe dusze (Mepmвые дуuи) Nikołaja Gogola zawierał rozdział poświęcony wspomnieniom o Awierczence. Powracając pamięcią do porewolucyjnej przeszłości, Teffi pisała:

Началось это приблизительно в 1909 году. Точно не помню. Я годы различаю не по номерам (год номер тысяча девятьсот такой-то), а по событиям. Время тогда было строгое. Смех не имел права на существование. Допускался только так называемый „смех сквозь незримые миру слезы”, пронизанный гражданской скорбью и тоской о несовершенстве человечества. (376)

W tym samym rozdziale autorka przypomniała słowa Benedykta Spinozy, a dokładniej ważne twierdzenie niderlandzkiego filozofa na temat wolności, które zwarł w IV części Poetyki (1677).

Analiza wskazanych fragmentów prowadzi nas do konkluzji, że w literackiej koncepcji Teffi śmiech pełnił funkcję terapeutyczną: „Да, ирония, сатира на нравы - это извольте, но свободный смех, о котором Спиноза сказал, что он «есть радость, а потому сам по себе благо», - это было неприемлемо" (Teffi 376). Ponadto śmiech pełnił w prozie wspomnieniowej rosyjskiej emigrantki rolę swoistej „siatki maskującej”. Predykatyw смешно znajduje zastosowanie w tych okolicznościach, które zdecydowanie nie 
należą do wesołych, a niekiedy wręcz stanowią zagrożenie dla zdrowia i życia bohaterów, pozostawiając w ich pamięci traumatyczny ślad (np. „- Давно вы здесь? Отчего не зашли попрощаться, когда уезжали? Мы о вас беспокоились. Смущенно разводит руками. - Как-то, знаете, все это так смешно устроилось...; „Доктор сказал, что после воспаления легких жить в нетопленой комнате с разбитыми окнами, может быть, и очень смешно, но для здоровья не полезно; „,- Оттуда попал на Волгу. До чего смешно! Флотом командовал. Ничего сражались").

Użycie wyróżnionego predykatywu nie odnosi się zatem do leksykograficznego objaśnienia, które wskazuje na sytuacje zabawne, ironiczny stosunek czy też ocenę czegoś, co wywołuje wrażenie komiczne, mogące rozśmieszyć. Śmiech w prozie wspomnieniowej Teffi realizuje platońską koncepcję śmiechu, którą za Rafałem Michalskim będziemy rozumieć jako demaskującą degradację uznanych ogólnoludzkich wartości i wynaturzenia ludzkiej natury: nikczemności, małostkowości, głupoty, okrucieństwa itp. (Michalski 153).

Obraz świata i ludzi przedstawiony we Wspomnieniach Teffi ukazuje $\mathrm{w}$ istocie komiczną deformację rzeczywistości pozostającej w stanie rozpadu. Autorka nie wyjaśnia w swoich zapiskach przyczyn opuszczenia Rosji, nie znajdziemy w nich także jednoznacznie wyrażonego stosunku do rewolucji. Miała jednak świadomość nieodwracalności zmian, które nastąpiły w jej kraju. Towarzyszące jej wówczas emocje utrwalała atmosfera oczekiwania na tragiczny finał, rozważania przepełnione strachem przed głodem, przemocą i utratą bliskich:

Теперь, когда мой отъезд устраивался, я почувствовала, как мне, в сущности, хотелось уехать. Теперь, когда можно было спокойно думать о том, что меня ждало, если бы я осталась, мне стало страшно. Конечно, не смерти я боялась. Я боялась разъяренных харь с направленным прямо мне в лицо фонарем, тупой идиотской злобы. Холода, голода, тьмы, стука прикладов о паркет, криков, плача, выстрелов и чужой смерти. Я так устала от всего этого. Я больше этого не хотела. Я больше не могла (Teffi 148).

\section{WNIOSKI}

Proza wspomnieniowa Nadieżdy Teffi to swoista kronika losów emigrantów rosyjskich. Autorka utrwaliła ten okres w dziejach Rosji, który był bezpośrednią konsekwencją przełomowych wydarzeń: rewolucji 1905 r. oraz 
przewrotu bolszewickiego w 1917 r. Emigrantka dokumentowała dokładny przebieg swojej wędrówki na trasie: Moskwa - Kijów - Odessa - Sewastopol - Noworosyjsk, a także barwny opis warunków życia w kolejnych miejscach pobytu. Przymusowa podróż po Rosji obfitowała w zapisy utrwalające wszystkie absurdalne i komiczne sytuacje, które przytrafiły się autorce i jej współtowarzyszom. Z dzisiejszej perspektywy autobiograficzny zapis jest traktowany jako powieść historyczna i cenne źródło informacji o ówczesnej sytuacji politycznej, realiach bytu oraz takich postaciach, jak: Arkadij Awierczenko, Aleksiej Tołstoj, Włas Doroszewicz, Maksimilian Wołoszyn i in. Narracja prowadzona jest z pozycji bohaterki bezpośrednio uczestniczącej w opisywanych wydarzeniach i osobiście znającej opisywane postacie. Zdaniem Lidii Spiridonowej, typowa dla reportażowego stylu Teffi narracja, przybierająca formę przejmującej, szczerej i emocjonalnej wypowiedzi, wskazuje na paralele z prozą autobiograficzną Maksyma Gorkiego ${ }^{8}$ Myśli nie na czasie (Несвоевременные мысли, 1918) oraz Iwana Bunina Przeklęte dni (Окаянные дни, 1925).

Jednocześnie jednak indywidualny styl autorki wspomnień cechowała reporterska spostrzegawczość, publicystyczność i demaskujący humor (Spiridonova 12-19; Reznik 231-237). Proza wspomnieniowa Teffi stanowi krytyczną refleksję porewolucyjnej rzeczywistości. Opisywane przez nią realia bolszewickiego terroru pełne były sprzeczności, paradoksów i niejednoznacznych postaw, w których z jednej strony brakowało powodów do radości, z drugiej radością było samo uniknięcie śmierci (np. „Они уже слишком многое видели и узнали, чтобы смеяться”; „Уверенность, что буквально никто не собирается нас расстреливать, наполняла душу радостным удивлением и довольством”; ,- Я боюсь, - говорила она. - Вдруг мужа сошлют в Сибирь. Он не выдержит, унего слабые легкие. И в ответ на эту законную тревогу послышалось подхихикиванье. - Ничего, не беда! Климат в Сибири здоровый. Это ему даже, хи-хи, полезно").

Dlatego też emigrantka chętnie sięgała po sprawdzone środki językowe, takie jak ironia, komizm postaci, żart sytuacyjny i zmienność intonacji, a także uniwersalne koncepty, w tym koncept CMEX:

\footnotetext{
${ }^{8}$ Zgodnie z przyjętą przez nas zasadą transpozycji imion i nazwisk rosyjskich imię Gorkiego powinno mieć formę Maksim. Jednakże w tym przypadku zdecydowaliśmy się zachować wariant utrwalony w literaturze przedmiotu (Nieuważny 140-143).
} 
Действительно, рассказ ведется нарочито простоватым тоном: мол-де, некая Тэффи была застигнута непогодой революции, непогода была ей неприятна. Тэффи об этом и пишет, как свидетельница и потерпевшая, - шутка, легкое шаржирование сменяются искренним недоумением, частой грустью, волной лирических вздохов. В конце концов, воспоминания эти, несмотря на авторское стремление снизить их содержание, сохранят несколько забавных, несколько трагичных, несколько деловых деталей эпохи. (Nikolayev 157).

Analiza lingwistyczna pokazuje, że koncept CMEX jest szeroko reprezentowany w prozie wspomnieniowej Nadieżdy Teffi ${ }^{9}$. Przeprowadzona analiza, którą ukierunkowaliśmy na wyodrębnienie semantycznej struktury konceptu CMEX oraz sposobów jego językowej reprezentacji, pozwala stwierdzić, że jego struktura jest złożona. Indywidualno-autorskie znaczenia reprezentujące peryferie analizowanego przez nas konceptu mają różną konotację. Uczucia i emocje wyrażane za pomocą śmiechu w świecie przedstawionym są zarówno pozytywne, negatywne, jak i neutralne. Wyodrębniając wyrażenia zawierające kluczowe słowo cмex, można zauważyć obecność elementów tworzących pole asocjacyjne, które wyrażają różne stany psychiczne i skrajne emocje. $Z$ jednej strony radość, zadowolenie, $z$ drugiej - strach, zmartwienie, smutek, niepokój, wątpliwość, niepewność, zdziwienie itd. Częstotliwości użycia jednostek leksykalnych oraz różnorodność ich aktualizacji świadczą o tym, że koncept CMEX zajmuje ważne miejsce w językowym obrazie świata rosyjskiej Teffi.

\section{BIBLIOGRAFIA}

Anusiewicz, Janusz. „Problematyka językowego obrazu świata w poglądach niektórych językoznawców i filozofów niemieckich XX w.”. Językowy obraz świata, red. Jerzy Bartmiński, Wydawnictwo Uniwersytetu Marii Curie-Skłodowskiej, 1990, ss. 277-307.

Anusiewicz, Janusz, Anna Dąbrowska i Michael Fleischer. „Językowy obraz świata i kultura. Projekt koncepcji badawczej”. Acta Universitatis Wratislaviensis, t. 13: Język a kultura, 2018, ss. 11-44.

Anusiewicz, Janusz. Lingwistyka kulturowa. Zarys problematyki. Wydawnictwo Uniwersytetu Wrocławskiego, 1994.

Bartmiński, Jerzy, i Ryszard Tokarski, „Językowy obraz świata a spójność tekstu”. Teoria tekstu. Zbiór studiów, red. Teresa Dobrzyńska, Zakład Narodowy im. Ossolińskich, 1986, ss. $65-81$.

${ }^{9}$ Por. frekwencję wyrazu cMex w Narodowym Korpusie Języka Rosyjskiego - 27886 (Natsional'nyy korpus). 
Bartmiński, Jerzy. „Słowo wstępne”. Etnolingwistyka, t. 1, 1988, s. 5.

Bartmiński, Jerzy. Językowe podstawy obrazu świata. Wydawnictwo Uniwersytetu Marii Curie-Skłodowskiej, 2007.

Churilina, L[yubov'] N[ikolayevna]. Leksicheskaya struktura khudozhestvennogo teksta (kommunikativnyy $i$ antropotsentricheskiy aspekty): Uchebnoye posobiye $k$ spetskursu. Izd-vo Magnitogorskogo gosudarstvennogo instituta, 2000 [Чурилина, Л[юбовь] Н[иколаевна] Лексическая структура художественного текста (коммуникативный и антропоцентрический аспекты): Учебное пособие к спецкурсу. Изд-во Магнитогорского государственного института, 2000].

Dmitrieva, L[yudmila]. „Semantiko-kognitivnoe opisanie konceptov „ulybka” / „smeh” v russkoj kartine mira". Visnyk L'vivs'koho universytetu. Seriyafilolohichna, vyp. 56, ch. 2, 2012, ss. 50-55 [Дмитриева, Л[юдмила]. «Семантико-когнитивное описание концептов „улыбка" / „смех” в русской картине мира». Вісник Львівського університету. Серія філологічна, вип. 56, ч. 2, 2012, сс. 50-55].

Dzyuba, Yelena. „Kontsepty zhizn' i smert' v poezii M.I. Tsvetanvoy”. Politicheskaya lingvistika, nr 15, 2015, ss. 181-189 [Дзюба, Елена. «Концепты жизнь и смерть в поэзии М.И. Цветаевой», Политическая лингвистика, № 15, 2015, сс. 181-189].

Grzegorczykowa, Renata. „Pojęcie językowego obrazu świata”. Językowy obraz świata, red. Jerzy Bartmiński, Wydawnictwo Uniwersytetu Marii Curie-Skłodowskiej, 1990.

Grzegorczykowa, Renata. „Punkty dyskusyjne w rozumieniu pojęcia językowego obrazu świata widziane z perspektywy badań porównawczych", Etnolingwistyka. Problemy Języka i Kultury, nr 21, 2009, ss. 15-29.

Językowy obraz świata, red. Jerzy Bartmiński, Wydawnictwo Uniwersytetu Marii Curie-Skłodowskiej, 1990.

Karasik, V[ladimir] I[1'ich]. Yazykovoy krug: Lichnost', kontsepty, dyskurs. Peremena, 2002 [Карасик, В[ладимир] И[льич]. Языковой круг: Личность, конщепты, дискурс. Перемена, 2002].

Karaulov, $\mathrm{Yu}$ [riy] $\mathrm{N}$ [ikolayevich]. Lingvisticheskoye konstruirovaniye i tezaurus literaturnogo yazyka. Nauka, 1981 [Караулов, Ю[рий] Н[иколаевич]. Лингвистическое конструирование и тезаурус литературного языка. Наука, 1981].

Kuznetsov, $\mathrm{Yu}$ [riy] A[leksandrovich]. Leksiko-semanticheskoye pole smekhakak fragment russkoy yazykovoy kartiny mira. Dissertatsiya na soiskanie nauchnoy stepenikandidata filologicheskikh nauk. Sankt-Peterburgckiy gosudarstvennyy universitet, 2005 [Кузнецов, Ю[рий] А[лександрович]. Лексико-семантическое поле смеха как фрагмент русской языковой картины мира. Диссертация на соискание научной степени кандидата филологических наук. Санкт-Петербургский государственный университет, 2005].

Michalski, Rafał. „Rozważania wokół platońskiej koncepcji śmiechu”. Studia z Historii Filozofii, nr 4 (6), 2015, ss. 149-174.

Natsional'nyy korpus russkogo yazyka, ruscorpora.ru/new/search-main.html [Национальный корпус русского языка, ruscorpora.ru/new/search-main.html]. Dostęp 31.07.2020.

Ndiaye, Iwona Anna. Pod maska Talii... O tożsamości poetyckiej Nadieżdy Teffi. Wydawnictwo Uniwersytetu Warmińsko-Mazurskiego w Olsztynie, 2019.

Nechvolod, A[leksandr] $\mathrm{Yu}$ [riy]. „Zhanrovoye svoyeobraziye knigi Teffi «Vospominaniya»”. Literatura v konteksti kul'tury. vyp. 22 (1), 2012, ss. 72-79 [Нечволод, А[лександр] 
Ю[рий] «Жанровое своеобразие книги Тэффи „Воспоминания”». Література в контексті культуры, вип. 22 (1), 2012, сс. 72-79].

Nieuważny, Florian, redaktor. Słownik pisarzy rosyjskich. Wiedza Powszechna, 1994.

Nikolayev, D[mitriy] D[mitriyevich]. „«Prazhskaya» kritika o tvorchestve N. A. Teffi”. Tvorchestvo $N$. A. Teffi i russkiy literaturnyyprotsess pervoy poloviny XX veka, red. $\mathrm{O}[\mathrm{leg}]$ $\mathrm{N}$ [ikolayevich] Mikhaylov, D[mitriy] D[mitriyevich] Nikolayev, Ye[lena] M[aksimovna] Trubilova, Naslediye, 1999, ss. 148-158 [Николаев, Д[митрий] Д[митриевич]. «“Пражская” критика о творчестве Н. А. Тэффи». Творчество Н. А. Тэффи и русский литературный проиесс первой половины XX века, ред. О[лег] Н[иколаевич] Михайлов, Д[митрий] Д[митриевич] Николаев, Е[лена] М[аксимовна] Трубилова, Наследие, 1999, с. 148-158].

Popadeykina, I. „Koncept śmierć w prozie Olgi Tokarczuk i Dmitrija Lipskierowa”. Rocznik Instytutu Polsko-Rosyjskiego, nr 1 (2), 2012, ss. 87-104.

Reznik, Oksana. „«Okayannyye dni» I. A. Bunina i «Vospominaniya» Teffi: Ukraina i grazhdanskayavoyna”. Kul'tura Narodov prichernomor'ya, nr 69, 2005, ss. 231-237 [Резник, Оксана. «“Окаянные дни” И. А. Бунина и ”Воспоминания” Тэффи: Украина и гражданская война». Культура народов Причерноморья, № 69, 2005, сс. 231-237].

Slovar' russkogo yazyka: v 4-kh tt., red. Anastasiya Yevgen'yeva. Russkiy yazyk, 1986 [Словарь русского языка: B 4-x тm., ред. Анастасия Евгеньева. Русский язык, 1986].

Slovar' sovremennogo russkogo literaturnogo yazyka, t. 13, S-Cnyat'sya, red. G. Galavanova, F. Sorokoletov, Akademiya nauk SSSR, 1962 [Словарь современного русского литературного языка, т. 13: С-Сняться, ред. Г. Галаванова, Академия наук СССР, 1962].

Spiridonova, Lidiya. „Protivleniye zlu smekhom”. Tvorchestvo N. A.Teffi i russkiy literaturnyy protsess pervoy poloviny XX veka, red. O[leg] $\mathrm{N}$ [ikolayevich] Mikhaylov, D[mitriy] D[mitriyevich] Nikolayev, Ye[lena] M[aksimovna] Trubilova, Naslediye, 1999, ss. 12-19 [Спиридонова, Лидия. «Противление злу смехом». Творчество Н. А. Тэффи и русский литературный процесс первой половины ХХ века, ред. О[лег] Н[иколаевич] Михайлов, Д[митрий] Д[митриевич] Николаев, Е[лена] М[аксимовна] Трубилова, Наследие, 1999, сс. 12-19].

Stepanov, Yu[riy] S[ergeyevich]. Kontsepty. Tonkaya plenka tsivilizatsii. Yazyki slavyanskikh kul'tur, 2007 [Степанов, Ю[рий] С[ергеевич]. Конџептьы. Тонкая пленка цивилизации. Языки славянских культур, 2007].

Sternin, I[osif] A[bramovich]. „Metodikaissledovaniya struktury kontsepta”. Metodicheskiye problemy kognitivnoy lingvistiki, red. I[osif] A[bramovich] Sternin, Voronezhskiy gosudarstvennyy universitet, 2001, ss. 61-63 [Стернин, И[осиф] А[брамович]. «Методика исследования структуры концепта». Методические проблемы когнитивной лингвистики, ред. И[осиф] А[брамович] Стернин, Воронежский государственный университет, 2001, сс. 61-63].

Teffi, Nadezhda. Moya letopis', sost., predisl., primech. St. Nikonenko. PROZAiK, 2015 [Тэффи, Надежда. Моя летопись, сост., предисл., примеч. Ст[анислава] Никоненко. ПРОЗАиК, 2015].

Tokarski, Ryszard. „Od językowego obrazu świata do obrazów świata w języku”, Język Polski, vol. 96, nr 2, 2016, ss. 28-37.

Tokarski, Ryszard. „Przeszłość i współczesność w językowym obrazie świata”. Przeszłość w językowym obrazie świata, red. Anna Pajdzińska i Piotr Krzyżanowski, Wydawnictwo Uniwersytetu Marii Curie-Skłodowskiej, 1999, s. 13. 
Tokarski, Ryszard. „Słownictwo jako interpretacja świata”. Encyklopedia kultury polskiej XX w., t. 2: Współczesny język polski, red. Jerzy Bartmiński, Wiedza o Kulturze - Instytut Filologii Polskiej UMCS, 1993, s. 366.

Vinogradov, Viktor. Russkiy yazyk. Vysshaya shkola, 1972 [Виноградов, Виктор. Русский язык. Высшая школа, 1972].

Żuk, Grzegorz. „Językowy obraz świata w polskiej lingwistyce przełomu wieków”. Przeobrażenia $w$ języku i komunikacji medialnej na przełomie XX $i$ XXI wieku, red. Małgorzata Karwatowska i Adam Siwiec, Państwowa Wyższa Szkoła Zawodowa w Chełmie, 2010, s. 239-257.

\title{
KONCEPTUALIZACJA ŚMIECHU \\ W JĘZYKOWYM OBRAZIE ŚWIATA NADIEŻDY TEFFI \\ (NA MATERIALE PROZY WSPOMNIENIOWEJ)
}

Streszczenie

W centrum uwagi badawczej Autorki pozostaje koncept CMEX w rosyjskiej literaturze emigracyjnej. Celem artykułu jest analiza danego konceptu w prozie wspomnieniowej Nadieżdy Teffi, pisarki pierwszej fali emigracji rosyjskiej. Przedmiot niniejszej analizy stanowi leksyka wyekscerpowana z tomów Wspomnienia (1933) oraz Moja kronika (2015). Analiza została ukierunkowana na wyodrębnienie semantycznej struktury konceptu oraz sposobów jego lingwistycznego wyrażenia w tekście literackim.

W procesie analizy odwołaliśmy się do metodologii zaproponowanej przez Josifa Sternina, co pozwoliło wyróżnić w strukturze konceptów różnorodne jednostki mentalne autorskiego obrazu świata, werbalizowane w tekstach literackich (sensy i wyobrażenia obiektywne oraz indywidualno-autorskie).

Ponadto w badaniu wykorzystano metodę opisową oraz analizę funkcjonalno-stylistyczną.

$\mathrm{Na}$ podstawie przeprowadzonej analizy lingwistycznej możemy wnioskować, że koncept CMEX jest szeroko reprezentowany w prozie wspomnieniowej Teffi. Indywidualno-autorskie znaczenia reprezentujące peryferie analizowanego konceptu mają różną konotację. Uczucia i emocje wyrażane za pomocą śmiechu w świecie przedstawionym są zarówno pozytywne, negatywne, jak i neutralne. Częstotliwości użycia jednostek leksykalnych oraz różnorodność ich aktualizacji świadczą o tym, że koncept CMEX zajmuje ważne miejsce w językowym obrazie świata Teffi.

Słowa kluczowe: Nadieżda Teffi; koncept ŚMIECH; językowy obraz świata; proza wspomnieniowa; rosyjska literatura emigracyjna.

\section{THE CONCEPTUALISATION OF LAUGHTER \\ IN THE LANGUAGE OF THE WORLD OF NADEZHDA TEFFI (BASED ON MATERIAL FROM HER PROSE MEMOIRS)}

\author{
Su m m ary
}

The focus of this research is the concept of Laughter in Russian émigré literature. The particular aim of this article is to analyse this concept in the memoirs of Nadezhda Teffi, one of the writers from the first wave of Russian emigration. The subject of this analysis is the lexis taken from the volumes Memoirs (1933) and My Chronicle (2015). The analysis focuses on distinguishing the semantic structure of the concept of Laughter, and the ways of its linguistic 
expression in the literary text. During the process of analysis, we refer to the methodology proposed by Josif Sternin which made it possible to distinguish, in the structure of concepts, various mental units of the author's image of the world as verbalised in literary texts (objective and individual-author meanings and images). Moreover, this study uses a descriptive method and a functional and stylistic analysis. Based on the linguistic analysis carried out, we conclude that the concept of Laughter is widely represented in Teffi's memoirs. The individual-author's meanings representing the periphery of the concept analysed have a different connotation. The feelings and emotions expressed through laughter in the depicted world are positive, negative and neutral. The frequency of use of the lexical units, and the variety of their updating, prove that the concept of Laughter has an important place in Teffi's linguistic worldview.

Keywords: Nadezhda Teffi; the concept of Laughter; linguistic picture of the world; prose memoir; Russian émigré literature. 